\title{
Survival Book to Help BIPA Learners Off the Hook of Culture Shock
}

\author{
Hespi Septiana*, Him'mawan Adi Nugroho, Warsita Noer Ardiyanti, \\ Masilva Raynox Mael, Agus Ridwan \\ Universitas Negeri Surabaya, Indonesia \\ *hespiseptiana@unesa.ac.id, himmawannugroho@unesa.ac.id., warsitana97@gmail.com, \\ masilvamael@unesa.ac.id, agus_unesa@yahoo.com
}

DOI: 10.20884/1.jli.2021.12.2.4915

\begin{abstract}
Article History:
First Received:

ABSTRACT

$11 / 10 / 2021$

Final Revision:

From time to time, Indonesian for Foreign Speakers (BIPA) continues to grow,

$15 / 12 / 2021$ including BIPA at the State University of Surabaya (Unesa). It cannot be denied that in its journey, BIPA Unesa encountered various problems. One of them is a report from a foreign student who was confused when he first arrived in Surabaya. Their confusion includes finding the ideal place to live, using

Available online: online motorcycle taxi applications, and using public facilities such as

$31 / 12 / 2021$ markets, hospitals, and police stations. Not only that, but the understanding of academic rules on campus has also not been able to be conveyed on target. Some local students and lecturers have helped, but the limited number and time have made it impossible to assist students. Therefore, this research focuses on making a pocketbook called "survival book" in five different languages for foreign students. The benefits of this research are expected to be able to solve the concerns of BIPA students when they first come to Surabaya with the development of a pocketbook. This research belongs to the category of product development. With this research, it is hoped that it will produce an output in the form of a survival book for BIPA Unesa students as well as scientific articles that will be published in accredited national journals.
\end{abstract}

Keywords: student problems; BIPA,; survival book; pocket book

\section{INTRODUCTION}

Culture shock is commonly experienced by anyone who moves from their place of origin to a new area to start a new life or study, as well as those experienced by Indonesian Language Learners for Foreign Speakers (BIPA). BIPA students come to Indonesia with the intention to deepen their ability to speak and learn Indonesian culture. During their study, BIPA students will face diverse culture, society, and local language, such as, Javanese, Sundanese, Balinese, and so on. It has to make them to adapt a new situation. 
Differences in culture, society, local language, temperature, food, and many more make BIPA students sometimes feel confused in responding to these situations appropriately, especially when they come to Surabaya, the second-largest city in Indonesia based on the census conducted by the Central Statistics Agency in 2010. With various cultures and people, the cases of culture shocks occur to every individual who study abroad for several times (Milton, 2005), including BIPA students. Studying outside their origin country into another country is a challenging task for international students while adjusting to the Indonesian culture.

Since 2017, BIPA students who study at BIPA State University of Surabaya (Unesa) will be accompanied by BIPA buddies. BIPA buddies are Unesa student community that accompany international students while studying at Unesa. They will help introduce life in Surabaya both from academic and non-academic fields such as socializing by using suitable greeting and greeting culture.

Based on a survey conducted from July to August 2019, 23 BIPA students who had studied in Surabaya said there was a culture shock when they first arrived, for example, being surprised by the number of motorbikes, causing traffic jams. Then, many of them find it strange when people they don't even know are so friendly and easy to smile. The surprise they feel, if they are not appropriately accommodated, will impact the learning process in the classroom. So, in addition to the teachers who gave explanations, BIPA buddies that is called Sahabat BIPA was there to help answer various things that made BIPA students wonder. However, some BIPA students are afraid of being inconvenient or want to understand Surabaya independently, so they are less comfortable when accompanied by BIPA Friends. Therefore, the researcher took the initiative to develop a pocketbook to survive during study in Surabaya.

This survival book is made in five languages: Indonesian, Japanese, Mandarin, German, and English. Later, the book is divided into two discussion chapters, namely the guide chapter on nonacademic questions, which contains general numbers that can be contacted by them such as hospital numbers, immigration, etc. Then, how to survive with a list of routines from the first day to the seventh day by introducing essential places such as hospitals, pharmacies, to police stations. In addition, this book introduces procedures for buying by bargaining and introduces markets, supermarkets, and malls. Also, in the academic chapter, the pocketbook contains regulations during the teaching and learning process at Unesa, such as dress codes in the university, rules for attendance and student activity, procedures for greeting academics, and the ethics of communicating with their teachers properly correctly. The most crucial point in this book is that there is an additional chapter of information about the culture of Surabaya, called the "Cultural Corner". 
Moreover, the cultural corner in the survival book will be a suitable media and help the BIPA learning process, both in and outside the classroom. To use textbooks or modules that are already available, teachers need to develop materials or media adapted to the characteristics of students or the peculiarities of the local culture (Septiana, 2020). Jamil (2016:4) says that learning media is everything related to software and hardware that can convey the content of teaching materials from learning resources to students (individuals or groups), which can stimulate the thoughts, feelings, attention, and interests of learners. Afterwards, the learning process (inside/outside the classroom) becomes more effective.

In the process, BIPA students have a variety of goals when deciding to study the Indonesian language, so it is essential for them to feel comfortable in learning so that their goals are achieved. According to Suyitno (2008: 10), international students who studying BIPA, have some goals, for instance, learning deeply the Indonesian language and getting to know Indonesian culture closely. The description of the BIPA learning objectives has implications for the preparation of learning materials following these objectives. Thus, this BIPA learning material has a close relationship with meeting the needs of foreign students, namely (1) the need for work, (2) the need for vocational training programs, and (3) the business professional (Nooriafshar, 2013).

The ideal learning process in supporting individual language skills is not only indoor but also outside the classroom. BIPA students also need to continue to pay attention to the teaching media used so that their abilities can quickly improve. Because the subject matter is the core of the learning process (Ade, 2011: 60). It means that learning material plays a vital role because one of the main goals of learning is to master the subject matter. To be a specific explanation, the learning process does not run without learning materials. In addition, making teaching materials more exciting and adaptive, teachers need to pay attention to the regional culture that can help students adapt. Culture is material that supports understanding the context of language because language and culture have a close relationship with everyday life (Kusmiatun, 2016: 65-66).

Then, the researcher decided to find a proper media for students to learn quickly in understanding the Indonesian language and culture through the Survival book pocketbook developed. The survival book presents information about life in Surabaya by giving a concrete visual display. Thus, it can support the function of learning media, namely a source of information with various advantages that attract readers (Gerlach and Elly in Anitah, 2008: 2). Moreover, the primary function of learning media that needs to be considered, according to Arsyad (2011: 15), is a teaching aid that affects the climate, conditions, and learning environment organized and 
created by the teacher. The existence of media in the learning process has a significant role and benefit, especially in BIPA teaching.

BIPA teaching is held in a multicultural atmosphere. Therefore, learning media is not only functions as a transmitter of linguistic material but also as a means of introduction to the understanding Indonesian culture. Thus, the role of BIPA learning media includes: (1) conveying linguistic material; (2) a stimulus for ideas for learners to produce spoken and written language, (3) growing interest and motivation to learn, interactive media will increase the enthusiasm of learners to be involved in all learning processes, both individually and in groups; and (4) supporting cross-cultural understanding (Kusmiatun, 2016: 99). Based on this explanation, it can conclude that learning media is a source of learning support information that motivates students to enjoy learning. Media can be objects, people, events that are used to understand knowledge, attitudes, and skills.

According to Meikahana et al. (2015), a pocketbook can also be used as media. A pocketbook is a small book containing written and pictures in the form of explanations that can direct or provide instructions and are easy to carry everywhere. Setyono et al. (2013) complete in their opinion that a pocketbook can be interpreted as a book that is small in size, light in weight, easy to carry everywhere, and can be read at any time. The advantages of using a pocketbook based on Indriana's opinion (2011: 64) is that the material is studied according to needs and interests, so it is fast in finding information, easy to carry anywhere, and has an attractive appearance equipped with pictures and colors. Nevertheless, according to Sanaky (2013: 21) the materials used for printing are difficult to pack in a short time. The preparation of printed learning materials takes a long time.

\section{MATERIALS AND METHOD}

This research uses an Educational Research and Development (R \&D) approach, which is a research method used to produce specific products and test their effectiveness. Borg \& Gall (2003:775) do the development with ten steps. The technique used in this study is based on observations that have been made through surveys using Google Forms.

\section{Research and collecting information step}

The information collected through literature review and field observations is the main thing. The data collected comes from the problems faced by foreign students. Therefore, the results of 
observations (teaching experiences) and surveys of international students who had come to Unesa will be the foundation for this research.

\section{Planning step}

Planning the activities carried out:

1. Identify the problems faced by foreign students when they first came to Surabaya

2. Based on identifying the problem, a pocketbook containing academic and non-academic information was developed, which is expected to help international students adapt to the Surabaya and Unesa campuses.

3. Determine the contents of the pocketbook

4. Arrange the work order of the preparation.

\section{Develop preliminary form of product step}

Developing the initial product form, namely compiling a pocketbook containing academic and non-academic information, is expected to help foreign students adapt to the Surabaya, specifically in Unesa.

\section{Preliminary field testing step}

The initial field test, the prototype of the Pocket Book of Life at the State University of Surabaya was consulted with BIPA experts, such as learning practitioners who evaluate the attractiveness in Survival Book, readability, and suitability of material content, format, and appearance.

\section{Main product revision step}

In this step, the product revisions carried out were: 1) Reviewing input from BIPA experts, 2) Rebuilding the Pocket Book of Life proto-type at the State University of Surabaya based on the results of initial field tests.

\section{Main field testing step}


This step will be tested the pocket-book prototype in Surabaya with a limited scale. This limited test selects research subjects from several BIPA students to find and adapt products to the needs of foreign students.

\section{Operational product revision step}

This step needs a revision of the Survival Book in Surabaya for BIPA learners based on the results in the limited test.

\section{Operational field testing step}

The Survival Book in Surabaya is practiced in the field on a small scale, namely to BIPA students.

\section{Final product revision step}

The team finished the product based on the operational results of field tests.

\section{Dissemination and implementation}

Disseminating the research results on the effectiveness and efficiency of the Survival Book of Life in Surabaya is the last step for this method. The aim is to make the easiest way for international students to survive at the State University of Surabaya.

\section{Research Matrix}

Table 1. Focus on Determination

\begin{tabular}{cll}
\hline No. & \multicolumn{1}{c}{ Details } \\
\hline 1 & The activities are: & Participatory Team Determination: \\
& - Researcher \\
& - BIPA teacher \\
& RIPA learner \\
& Research site selection: BIPA Unesa \\
& Identify and solve problem \\
& - The first survey (interview, discuss, and \\
& - Discussing a problem-solving with team \\
& Understanding context \\
& The first survey \\
& - Literature review \\
& - Identify the character of BIPA learner \\
& - The analyze of needs
\end{tabular}


2 The final result is preliminary survey data and draft product specifications.

3 The used instrument is observation sheet, interview sheet, questionnaire sheet.

Table 2. Focus on Design and Development

\begin{tabular}{cll}
\hline No. & \multicolumn{1}{c}{ Items } & \multicolumn{1}{c}{ Details } \\
\hline 1 & The activities are: & $\begin{array}{l}\text { Choosing product and format The } \\
\text { selected product is a pocket-book for } \\
\text { international students who study in }\end{array}$ \\
Unesa. \\
Product Prototype Development: the \\
characteristic of product in specific. \\
Evaluation strategy \\
includes some activities to test the \\
effectiveness of prototypes/development \\
drafts through user reviews and expert \\
\end{tabular}

Table 3. Focus on Design and Determination

\begin{tabular}{cll} 
No. & \multicolumn{1}{c}{ Items } & \multicolumn{1}{c}{ Details } \\
\hline 1 & The activities are: & $\begin{array}{l}\text { Evaluating } \\
\text { Revising } \\
\text { Produing final product }\end{array}$ \\
2 & $\begin{array}{l}\text { The final results are revised printed and } \\
\text { electronic the Survival Book. }\end{array}$ & \\
3 & $\begin{array}{l}\text { The used instrument is questionnaire } \\
\text { sheet. }\end{array}$ & \\
\hline
\end{tabular}

\section{RESULTS \& DISCUSSION}

The process of the survival book for foreign students chooses a development method known as Research and Development. To help BIPA students studying at Unesa, the pocketbook for surviving in Surabaya was first equipped with detailed visuals and important numbers such as the 
nearest police station and hospital. The Survival book has five foreign languages that could make it easier for BIPA learners.

\section{Research and collecting information step}

In this section, the researcher distributed a survey via google form to BIPA students who have studied at BIPA Unesa. As many as $77,9 \%$ of students considered that the existence of a survival book was very crucial. Thus, researcher has been choosing the survival book to tackle this issue.

\section{Planning step}

In the second step, the researcher planed the content included in the book based on the problems collected from Google Form that has been given to the students. According to survey results, $77,9 \%$ of students stated that information on essential places in Surabaya needs to be included in the book. Furthermore, information on application support activities, examples of simple dialogues, information about life on the Unesa campus, conditions in Surabaya, places of entertainment, and basic level slang. From several ideas submitted by the students, the researcher arranged the order of the material and the work order of the preparation.

\section{Develop preliminary form of Product}

There are several topics that suit the needs of students. The researcher decided to add a topic, namely "Cultural Corner." The cultural corner contains greeting procedures that cannot directly mention names to everyone, politely dressed, how to eat, the shape of the bathroom, most Indonesians are Muslim, and many Indonesians often ask for photos with foreigners.

In addition, some subjects are included along with related vocabulary and short dialogues that can be done in the following places:

$>$ airport,

$>$ some important places, such as: public health center, traditional market, hotel, apartment, dormitory, bank, pharmacy, and mall),

$>$ public transportation,

$>$ a useful application, for instance: Gojek, Grab, Shopee, etc.,

$>$ entertainment area and historical place in Surabaya,

$>$ restaurant and food street vendors (warung), an

$>$ Indonesian currency. 


\section{Preliminary field testing step}

After compiling and designing the contents of the survival book, which is culture corner, the researcher conducted a validation test on several experts, including linguists, material/content experts, and graphic design experts, to assess the book's appearance. Here is the first result of validations from expert in language, design, and content.

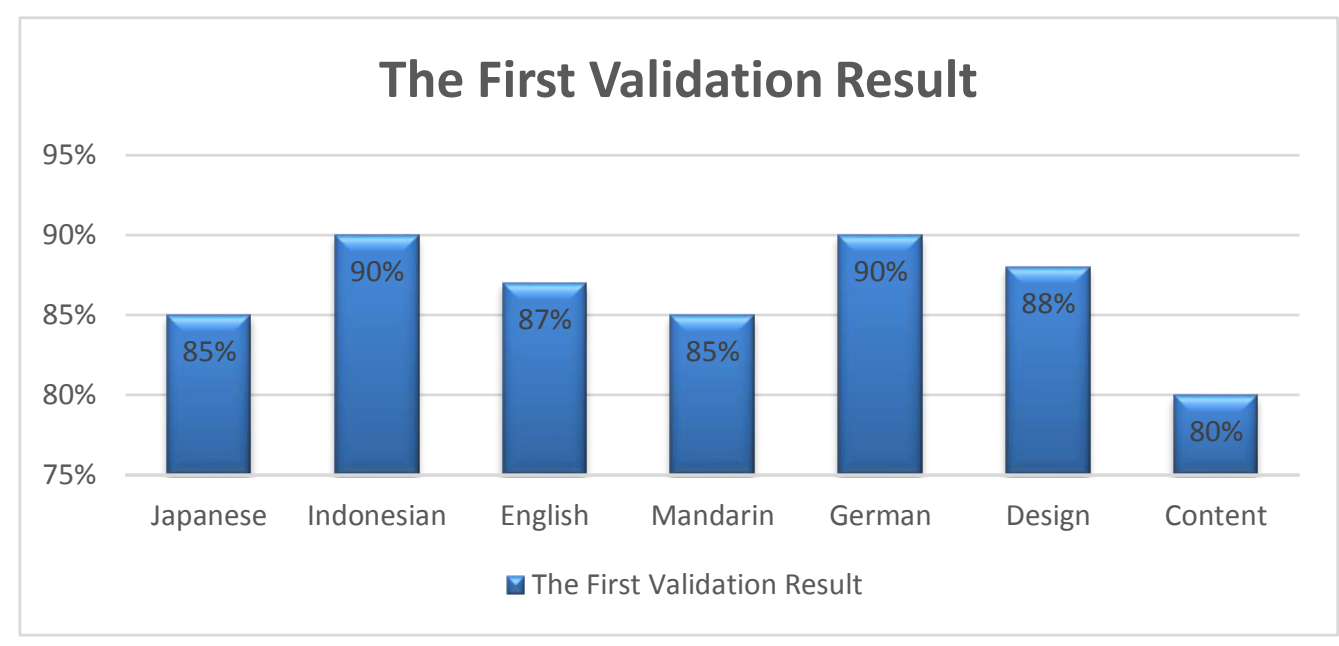

The languages validity test got an average of $87.4 \%$ from five languages in the language quality, which means very good. However, some language validators gave notes that book will be more convenient if the chosen words or sentences are not too complex because it is only for supporting daily activity and needs. Moreover, the quality of the material or content, this pocketbook gets a score of $80 \%$, which means it is valid, quality but needs a little addition. Then, in testing the book display design, it managed to get a score of $80 \%$, which means it is terrific.

\section{Main product revision step}

The results of product validation state that the content component needs a little extra so that the quality of the survival book is ready to use. In this part, student gave feedback during the first experiment. 


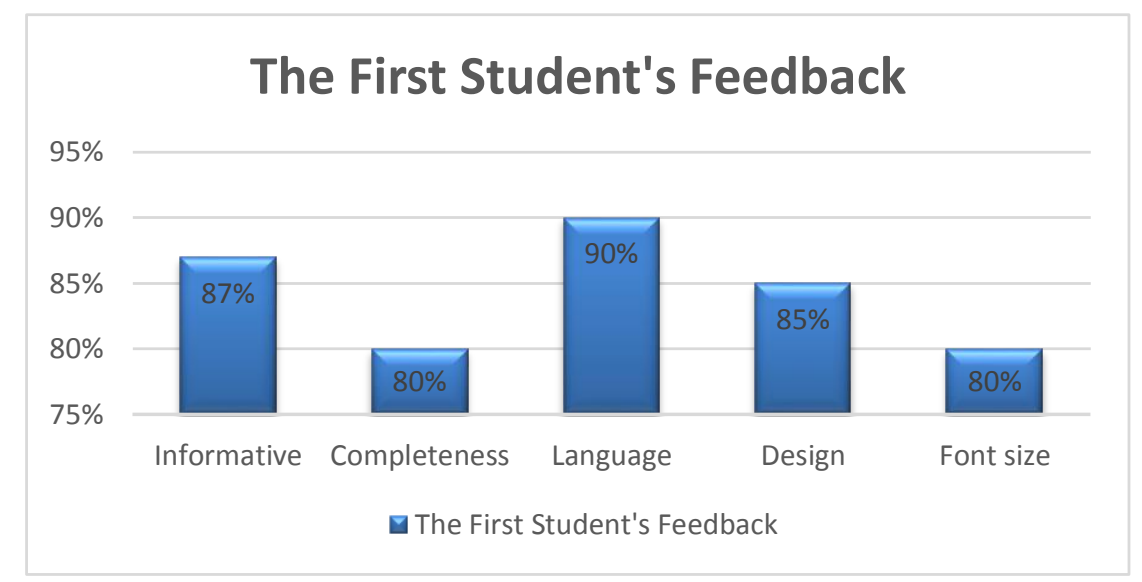

BIPA students said that the culture corner in survival book has excellent and informative content by giving $87 \%$ score in total. The second point, about the completeness, was $80 \%$. It means the information about culture corner was good, but it needed more information. The survival book also provides five languages, which helps BIPA students, so they gave $90 \%$ for this book, which means very good.

The design and font size had different achievements, each getting $85 \%$ and $80 \%$. It means font size had to change based on the student's note on feedback. Here are some suggestions from students for completing the survival book content, such as:

$>$ need more information about Indonesian bank,

$>$ compelling entertainment place, for instance, mall, park, night market, etc.,

$>$ Indonesian time zone,

$>$ tribes in Surabaya, and

$>$ the font size makes it bigger.

According to those suggestions, the content has been changed and revised to help readers, especially BIPA students, to be more readable and get the easiest way to survive during their study in Surabaya.

\section{Main field testing step}

After considering and revising the previous step, in this section, the Survival book was tested to BIPA learners who have lived in Surabaya. First, they read the Survival book and gave their opinion about the book's quality before publication widely. The selection of students was based on their native language that was used in the Survival book, namely Mandarin, German, English, and Japanese. Here are some names and the origin of their countries. 
Table 4. Names and the Origin of Their Country List

\begin{tabular}{ccc} 
No. & Initials & Country \\
\hline 1 & SD & Poland \\
2 & AY & Japan \\
3 & OB & Germany \\
4 & ST & Japan \\
5 & MX & China \\
6 & LJ & China \\
7 & NR & Latvia \\
\hline
\end{tabular}

During experiment, BIPA students filled in the last feedback for the survival book, especially focused on part culture corner. Most of them said that it can help BIPA students who will have first experience live in Surabaya. The survival book will be a guideline for understanding Surabaya people and Surabaya's traditions. Also, this book helps them to survive while in Surabaya because it resumes almost all information about Surabaya. Furthermore, its size is not too heavy, so then it does not take much space.

\section{Operational product revision step}

Testing with several BIPA students gave some constructive feedback in the form of diction selection to make it easier for native speakers to understand. In addition, from the limited trials carried out, there were additional ideas in the cultural corner, such as the Indonesian view of time (tolerance for each person), the prohibition of drinking alcohol, and the habit of Indonesians who mostly like spicy food. Those advise gave to validators for considering the final validation score and complemented idea for the Survival book. Here is the final score comparing with the first feedback.

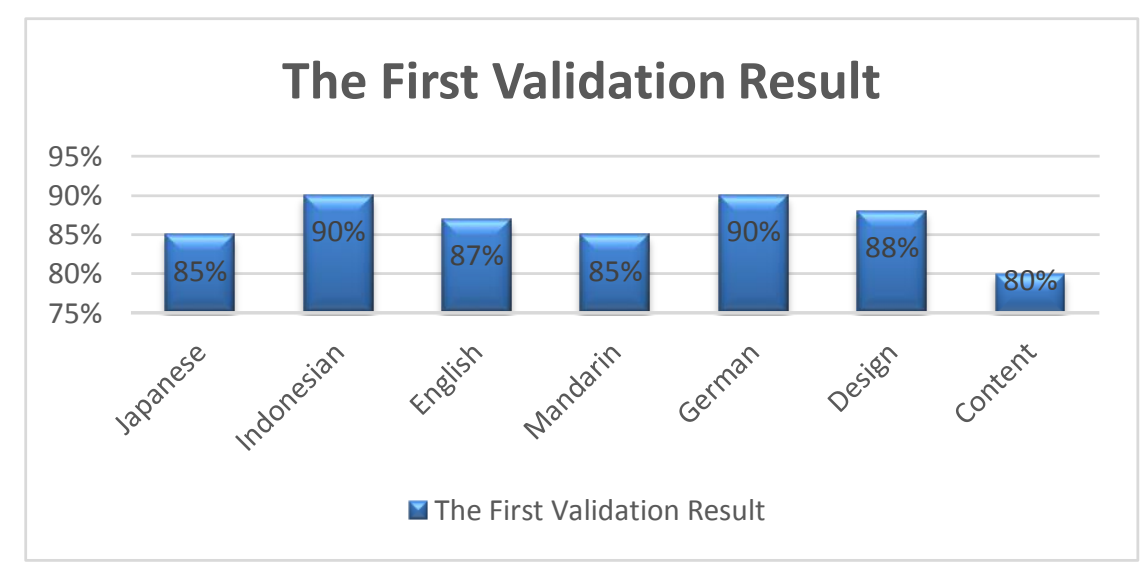




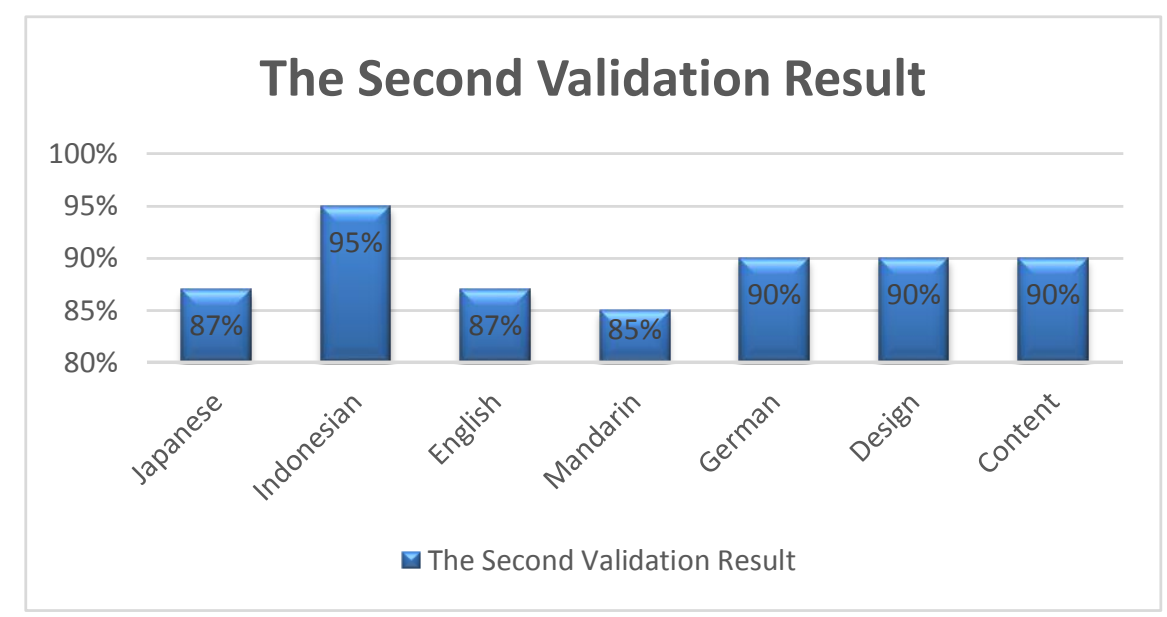

As we can see, there are several changes in some points, such as Japanese, Indonesian, design, and content. Afterwards, the survival book has been ready for BIPA students.

\section{Final product revision step}

After conducting several stages of testing, the survival book with the culture corner content was finalized. According to the previous feedback, the existing diction is corrected to minimize writing errors before printing. Moreover, the design of the book was also refined to make it more attractive and communicative. The content and font size were already changed.

\section{Dissemination and implementation}

The last step of this research is printing and publishing. Furthermore, the survival book will distribute among the Surabaya State University, especially BIPA department, to help and make it easier for international students to survive while studying at Unesa, especially in Surabaya. It also possible that it will be widely used for public who need it.

\section{CONCLUSION}

The development of culture corner in the survival pocket book for BIPA learner got an excellent result. It was based on the results from validators and the feedbacks of the BIPA students who have studied in BIPA Unesa. This is shown from the results of the validation test of linguists who scored $86.7 \%$, material/content experts $80 \%$, and graphic design experts who gave a score of $90 \%$. When tested on seven foreign students from various countries, although there were some feedbacks, such as more information about Indonesian bank, entertainment places, Indonesian time zone, tribes in Surabaya, and font size, they liked this book because it will help BIPA students who 
come for studying in Surabaya. Therefore, the survival book, which was made into a pocketbook, is effective in helping Unesa BIPA, because it is portable and not too heavy for them.

\section{ACKNOWLEDGEMENT}

We acknowledged Lembaga Penelitian dan Pengabdian Masyarakat (LPPM) Universitas Negeri Surabaya as a funding supporter for this research.

\section{REFERENCES}

Anitah, S. (2008). Media Pembelajaran. Surakarta: Panitia Sertifikasi Guru Rayon 13 Surakarta.

Arsyad, A. (2011). Media Pembelajaran. Jakarta: PT Raja Grafindo Persada.

Borg, W. R, Gall, M. D. Gall, J. P. (2003). Educational Research: An Introduction ( $7^{\text {th }}$ ed). Boston, M.A: Allyn and Bacon.

Indriana, D. (2011). Ragam Alat Bantu Media Pembelajaran. Yogyakarta: Diva Press.

Jamil, N. (2016). Media dan Sumber Pembelajaran. Jakarta: Kencana.

Kusmiatun, A. (2016). Mengenal BIPA dan Pembelajarannya. Yogyakarta: K. Media.

Meikahana, R. (2015). Pengembangan Buku Saku Pengenalan Pertolongan Perawatan Cedera Olahraga untuk Siswa Sekolah Menengah Pertama. Jurnal Ilmu Keolahragaan, 11:1.

Milton, T. J. (2006). Understanding Culture Shock. Retrieved January 9, 2006. From http://www.faoa.org/journal/cshckfao.html

Nooriafshar, M. (2013). "How Learning a New Language Can Benefit Business Professionals". The European Journal of Social \& Behavioural Sciences, https://www.researchgate.net/publication/257931875_How_Learning_a_New_Language

Can_Benefit_Business_Professionals

Sanjaya, A. (2011). Model-model Pembelajaran. Jakarta: Bumi Aksara.

Sanaky, A. H. (2013). Media Pembelajaran Interaktif-Inovatif. Yogyakarta: Kaukaban Dipantara

Richards, J. C., \& Renandya, W. A. (2002). Methodology in Language Teaching: An Anthology of Current Practice. Cambridge University Press.

Septiana, H. (2020). The Use of Kasino (Synonym Word) Learning Media in the Intermediate Grammar Class of BIPA. Atlantis Press, 491: 941—944.

Setyono. (2013). Pengembangan Buku Saku Materi Pemanasan Global untuk SMP. Unnes Journal of Biology Education, 4:1.

Suyitno, I. (2005). Bahasa Indonesia untuk Penutur Asing: Teori, Strategi, dan Aplikasi Pembelajarannya. Yogyakarta: CV Grafika Indah. 
Survival Book to Help BIPA Learners Off the Hook of Culture Shock in Surabaya (Hespi Setiana, Himmawan Adi Nugroho, Warsita Noer Ardiyanti, Masilva Raynox Mael, Agus Ridwan)

Suyitno, I. (2008). Dimensi Teoretis dan Metodologis Belajar Bahasa Asing, Landasan Teori Pembelajaran BIPA. Malang: Cakrawala Indonesia. 